\title{
POLICY IMPLEMENTATION OF TEACHER COMPETENCE IN PRACTICING ISLAMIC TEACHING
}

\author{
Acep Heris Hermawan \\ Universitas Islam Negeri (UIN) Sunan Gunung Djati Bandung \\ Jl. A. H. Nasution No.105, Cibiru, Bandung, Jawa Barat, Indonesia 40614 \\ Email: herishermawan@uinsgd.ac.id

\section{Hary Priatna Sanusi} \\ Universitas Islam Negeri (UIN) Sunan Gunung Djati Bandung \\ Jl. A. H. Nasution No.105, Cibiru, Bandung, Jawa Barat, Indonesia 40614 \\ Email:harypriatna@uinsgd.ac.id

\section{Maemunah Sa'diyah} \\ Universitas Ibnu Khaldun \\ Jl. K. H. Sholeh Iskandar KM. 2, Bogor, Jawa Barat, Indonesia 16162 \\ Email:maemunah@fai.uika-bogor.ac.id
}

Received: 11, 2017. Accepted: 12, 2017. Published: 12, 2017.

\begin{abstract}
This study aimed to find out the implementation of teacher competence, the practice of Islamic teaching, supporting and inhibiting factors of the implementation of teacher competence policy. The research used qualitative approach, and was conducted at MAN (Madrasah Aliyah Negeri/Islamic Senior High School) 1 Bandung, MAN Cipasung Tasikmalaya, and MAN Ciwaringin Cirebon. The data were collected through observations, interviews, documents, and questionnaires. The study found that the implementation of a policy in Islamic schools model had been running effectively. The teachers' competence had complied professionalism standard. The practice of Islamic teaching had described the dimension of religious practices dynamically and systematically. The supporting factors consisted of a qualified manpower, adequate structures and infrastructures, the atmospheres of excellent academic and spirituality, and the support from all elements of madrasa. The implication of the policy implementation of teacher competence in cultivating the practice of religious teaching in madrasas contributed to the improvement of madrasa quality, teacher competence and performance, and students' good deed and achievement.
\end{abstract}

Keywords: Policy Implementation, Religious Teachings, Teacher Competence.

\begin{abstract}
ABSTRAK
Artikel ini memaparkan tentang implementasi kebijakan kompetensi guru, pengamalan ajaran Islam, dan faktor pendukung dan penghambat kebijakan kompetensi guru. Penelitian menggunakan metode kualitatifyang dilakukan di MAN 1 Bandung, MAN Cipasung Tasikmalaya, dan MAN Ciwaringin Cirebon. Data dikumpulkan melalui observasi, interview, documen dan kuesioner. Temuan penelitian menunjukan implementasi kebijakan kompetensi guru di ketiga madrasah tersebut berjalan secara efektif. Kompetensi guru menentukan profesionalisme guru. Pengamalan keagamaan telah merefeleksikan pengamalan keagamaan secara dinamis dan sistematis. Faktor pendukung berupa sumberdaya berkualitas, struktur dan sarana prasarana yang baik, atmosfir keunggulan akademik dan spiritualitas serta dukungan dari semua pihak di madrasah. Implikasi dari implementasi kebijakan kompetensi guru dalam menumbubkan pengamalam keagamaan di madrasah telah berkontribusi terbadap perbaikan kualitas madrasah, peningkatan kompetensi guru, peningkatan prestasi siswa.
\end{abstract}

Kata Kunci: Implementasi Kebijakan, Ajaran Agama, Kompetensi Guru. 


\section{INTRODUCTION}

Education policy is public policy in the field of education. As stated by Olsen, Codd and O'Neil (2000), education policy is the key to excellence, even existence for countries in global competition, so that education policy needs to be given top priority in the era of globalization. Edward III (1980) advises to pay attention to four main issues to the effective policy implementation, namely, communication, resources, disposition or attitudes, and bureaucratic structures. Without effective implementation the decision of policy makers will not be carried out successfully.

Communication indicates that any policy will be implemented properly if there is an effective communication between program implementers (policy) and target groups. The resources related to each policy must be supported by adequate resources, both human and financial resources. Disposition, relates to the characteristics that are closely attached to the policy/program implementer. The bureaucratic structure points out that the bureaucratic structure is important in policy implementation (Indiahono, 2009, pp. 31-32).

According to Edwards (1980), the first requirement of an effective policy implementation is that those who implement the decisions must know what they should do. Policy decisions and orders should be forwarded to the right authorities before the decisions and orders are followed. Indeed, the communications must be accurate and should be understood carefully by the implementers. Teachers' competence is a qualitative description of the nature of meaningful teachers' behaviors. It includes a set of knowledge, skills and behavior that must be owned, experienced, and mastered by teachers or lecturers in implementing professional duties (The Ministerial Regulation of Indonesia No.14 of 2005 regarding Teachers and Lecturers).

Pedagogic competence is a competency that encourages teachers to have the ability to understand students, to design, and implement learning, to evaluate learning outcomes and to develop learners to actualize their various potentials ("Law no. 14 on teachers and lecturers," 2005). In addition to pedagogic competence, teachers should embrace personality competence. It refers to personal ability that reflects a steady, stable, adult, dignified personality and noble character so that they become role models for learners ("Law no. 14 on teachers and lecturers," 2005).

The Ministerial Regulation of Religious Affairs of the Republic of Indonesia No. 16 of 2010 on the Management of Religious Education in Schools provides additional competence. Additional competence for religious teachers in this regulation entails the competence of leadership. It is an ability to influence others and it contains a series of actions or behaviors in order to perform it. It implies that leadership category means building a culture of good behavior to be followed by others. Therefore the practice needs to be interpreted broadly, not just performing congregational prayer, reciting Qur'an, but also preserving culture of smiling, greetings, study ethos, and discipline. They are religious culture embodied through exemplary, habituation and internalization (Muhaimin, 2009, p. 313).

According to the Law of Teachers and Lecturers No. 14 of 2005 mentioned that teachers are required to have academic qualifications and competencies. Competencies that need to be owned by teachers include pedagogic, personality, social and professional competence. In addition to the Regulation of Teachers and Lecturers No. 14 of 2005, regulations relating to teacher competence particularly for religion teachers are contained in Ministerial Regulation of Religious Affairs No. 16 of 2010 on Management of Religion Education at School. It is said that teachers of Islamic education should have pedagogic, personality, social, professional, and leadership competencies. The leadership of teachers is related to the role of teachers in realizing Islamic teaching. Especially for Islamic education teachers that should possess spiritual competence in accordance with the Decree of the Minister of Religious Affairs No. 211 of 2011. 
Preliminary study in 2010 was conducted by distributing questionnaire to the teachers in several districts namely Bandung, Garut and Indramayu West Java covering PAI teachers in Islamic elementary school, Islamic Junior high school, kindergarten and Islamic elementary school. The study found that there was a problem concerning teachers who had not good knowledge and understanding concerning policy on teacher leadership competence which is stated in Ministerial Regulation of Religious Affairs No. 16 of 2010. This was a problem on the part of the teachers. It would be difficult for them to implement the policy because they had no proper understanding on the policy. How could this problem occurred was the question that need to be addressed. The source of the problem might refer to the aspect of communication, source, aattitude and bureaucracy structure in the policy implementation.

Another in-depth study was conducted in 2013 to investigate teachers' competence concerning teachers' leadership competence implementation in several madrasas located in MAN I Bandung, MAN Cipasung Tasikmalaya and MAN Ciwaringin Cirebon. The results showed that teachers were lack knowledge and understanding of emerging new policies related to competence. It is important to find out the solutions to the implementation of teacher competence policy to increase or optimize the quality of education. The above issue is interesting to examine and it leads to the investigation of the main factor or constraint that trigger the problem to appear. The cause may be the aspects of communication, resources, attitudes or bureaucratic structures in policy implementation. Those aspects serve as the focus of this research and they include: policy implementation, aspects of teacher competence, aspects of practicing Islamic teaching, supporting and inhibiting factors, advantages and shortages. In the end section of this paper, conceptual model on policy implementation of teacher competence is offered. The conceptual model focuses on principles and programs of communication, resources, attitude and bureaucratic structures aspects.

\section{METHOD}

This research used qualitative approach with descriptive-analytic method. Sources of data were collected from Madrasa Principals, Vice-principals, teachers' council, administrators and students of MAN I Bandung, MAN Cipasung Tasikmalaya and MAN Ciwaringin Cirebon. Techniques to collect data include interviews, observation, questioner, and documentation. In this study, data analysis was done by several stages, namely: data collection, data reduction, display data, conclusion and verification of data. In addition this study also implemented editing, categorization/coding, and meaning making. In the data editing process, the data were translated and converted. Furthermore, the data that could not be read then it was translated to be readable and understandable. In the coding stage, data categorization was applied in accordance with the focus of research problems. To gain meaning, this study interpreted the analyzed data according to focus of problem to be given meaning. Conceptualization of scientific statement was also added as the conclusion of the research.

\section{RESULTS AND DISCUSSION Implementation of Teacher Competency Policy}

Finding of this study showed that MAN 1 Bandung, MAN 1 Cipasung, MAN 1 Cirebon had certain principles and patterns in implementing teacher competence policy. To elaborate further, this study will explain the principle and pattern that were shared among those three schools. The first aspect concerning the principle and pattern to deal with in this section is communication. Communication aspect at MAN 1 Bandung was carried out in several ways covering: 1) optimizing the role of vice principal of school in the field of public relations; 2) Functioning administration on administrative products such as formal letters; 3) expanding 
technology facilities; 4) empowering community support; 5) intensifying socialization and communication (Hamzah, personal communication, June, 11, 2014).

In MAN Cipasung Tasikmalaya, communication was implemented through several ways namely: 1) communicating regularly; 2) communicating by various ways; 3 ) considering effective time; 4) conducting formal meeting mechanism; 5) optimizing supervision; 6) using cultural approaches; and 7) maximizing co-teachers (Ida, personal communication, June, 9, 2014). In MAN Ciwaringin Cirebon, implementation of teacher competency policy in practicing Islamic teaching through communication aspect was carried out by various methods including: 1) instilling the awareness of responsibility; 2) reminding the teachers' main tasks and functions; 3) making effective and smooth communication; 4) maximizing the quality of communication; 5) informing the importance of providing best service; and 6) reminding that the purpose of the teaching profession is to be a good servant of the state (Alhakim, personal communication, June, 10, 2014).

In the aspect of resources, one of the key factors in policy implementation, MAN 1 Bandung was that it had professional resources. Teachers, as the main resource in the implementation of policy in school, had been certified. This allowed the policy to run smoothly. The descriptions of the teacher's abilities are: 1 ) teachers as policy implementer have the ability to implement policies; 2) teachers have the ability to understand the policy implementation guidelines; 3) teachers have a high discipline in running the policy; 4) teachers have special authority in running the policy; 5) teachers conducted persuasive approach toward their authority; 6) the teacher have the ability to make beneficial value offers from the policy; 7) teachers have the ability to use facilities in running the policy; 8) schools have facilities in running the policy (Hamzah, personal communication, June, 11, 2014).

In MAN Cipasung, the resource aspect in the implementation of the policy of teachers has been professionally proven by professional educator certificates. The improvement of resources in MAN Cipasung Tasikmalaya has been done by several ways, there are: 1) planning through schedule-making procedures; 2) implementing measurable principles and planned according to available facilities; 3) conducting information informal activities; 4) providing warnings according to authority; 5) warnings according to certain authority (Ipit and Amay, personal communication, June, 9, 2014). In MAN Ciwaringin, resources were developed through several principles, there are: 1) increasing the quality of human resources simultaneously; 2) performing through an individual approach; 3) improving the quality of human resources institutionally; 4) establishing institutional programs and structures; 5) improving the capabilities of teachers; 6 ) encouraging to improve teachers' capacity; 7) increase professionalism in the field; and 8) making efforts to improve teachers' skills and experience (Ida, personal communication, June, 9, 2014).

Related to the attitude, one of the key factors in policy implementation, in MAN 1 Bandung, the teachers, as the main actors in the implementation of policy in school had professional attitude in implementing the policy. If there were teachers who were lack of professional attitude, the principal as a leader provided some steps as solutions. There were: 1) reminding indirectly through lecture activities, 2) providing indirect information through preaches, 3) reminding certain moments. The attitudes of teachers in implementing the policy are: 1) teachers have professional attitudes in running the policy; 2) teachers have wisdom in implementing the policy; 3) teacher makes decisions in implementing the policy; and 4) teachers implemented the policy (Yadi, personal communication, June, 11, 2014).

In MAN Cipasung, the attitude of the teachers as the implementers of the policy can be depicted as follows: 1) there are teachers who still hade difficulties in implementing the policy; 2) teachers already have wisdom in making decisions; 3) teachers initiate to implement the decision;and 4) teachers accept the policy well. The attitude of teachers of MAN Ciwaringin 
Cirebon in implementing the policy can be depicted as follows: 1) teachers are obedient to the policy; 2) teachers put forward deliberation in implementing the policy; 3) teachers give priority to service in running the policy; 4) teachers carry out the policy based on quality improvement (Delis, personal communication, June, 9, 2014).

Bureaucracy aspect at MAN 1 Bandung in running the policy of teacher competence in the practice of Islamic education can be described as follows: 1) bureaucracy have provided guidelines for policy implementation either in either hard or soft file; 2) bureaucracy have the readiness to implement the policy; 3) bureaucracy have the ability to achieve different goals; 4) the bureaucracy have the ability to run the policy in a complex and broad ways; and 5) bureaucracy have the ability to survive (Hamzah, personal communication, June, 11, 2014).

In MAN Cipasung, Tasikmalaya, the bureaucracy of implementation of teacher competency policy was as follows: 1) bureaucracy in implementing teacher competency policy was oriented towards improving teacher competence; 2) bureaucracy have priority in implementing the policy; 3) bureaucracy have authority in running the teacher competency policy; and 4) bureaucracy have the ability to run Standard Operating Procedures (SOP) in the implementation of teacher competency policy (Ida, personal communication, June, 9, 2014).

In MAN Ciwaringin, Cirebon, bureaucratic aspects in implementing teacher competency policy could be depicted as follows: 1) bureaucracy have provided guidelines for the implementation of teacher competency policy; 2) bureaucracy have the ability to be wise in understanding diversity; 3) bureaucracy is flexible in running SOP; 4) bureaucracy have the ability to overcome organizational fragmentation (Juju, personal communication, June, 10, 2014).

\section{Teacher Competence}

Teachers' competence in MAN 1 Bandung can be described as follows: 1) teachers have the ability to plan goal setting in learning; 2) teachers have the ability to set achievement of competence; 3) teachers have the ability to motivate learners; 4) teachers have the ability to manage learning; 5) teachers have the ability to understand the level of intelligence of learners; $6)$ teachers have the ability to understand the diversity of learners; 7) teachers created a creative learning process; 8) teachers have the ability to keep emotions; 9) teachers have the ability to act wisely toward learners; 10) teachers have authority in front of learners; 11) teachershave speechdelivering skills; 12) teachers have the ability to set cultural goals of Islamic education teaching; 13) teachers have the ability of developing a strategy of cultural practice of Islamic education teaching (Hamzah, personal communication, June, 11, 2014).

In MAN 1 Bandung, the above teacher abilities were nurtured and developed by school or institution by considering the following principles: 1) maintaining and developing professionalism regularly; 2) making efforts on improving competence; 3) developing teachers through training programs; 4) inviting trainers who have competence in their field; and 5) carrying out surveillance regularly. Activities developed by MAN 1 Bandung included: 1) conducting training on curriculum 2013;2) conducting deliberation among teachers; and 3) studying lesson issues (Yadi, personal communication, June, 11, 2014).

MAN Cipasung has professional teachers. The description of professionalism of MAN Cipasung teachers are: 1) teachers have the ability to develop students' self-confidence; 2) teachers have the ability to provide opportunities for students to communicate freely and directed; 3) teachers have the ability to involve students in determining learning goals; 4) teachers have the ability to supervise learners but not too authoritative; 5) teachers have the ability to prepare the lesson plans; 6) teachers have the ability to recognize students' learning outcomes; 7) teachers have the ability to guide and give counseling; 8) teachers have the ability to realize mistakes; 9) teachers have the ability keep relationship; 10) teachers have the ability to 
take responsibility; 11) teachers have the ability to be friendly to learners; and 12) teachers have the ability to give praises and rewards (Ida, personal communication, June, 9, 2014).

The development of teacher competence in the practice of Islamic education teaching is done by the Principal of MAN Cipasung together with other school elements based on several principles, they are: 1) encouraging teachers to own and improve their competence; 2) conducting periodic training effort; 3) helping teachers to adjust to the development of the situation; 4) making efforts to improve teachers' ability on guiding aspect; 5) encouraging teachers to have cooperative skills; 6) conducting activities of teachers by involving the community; 7) supervising the implementation of teacher duties; 8) creating a special institution managing teacher competence; 9) conducting meetings among teachers on similar subjects; 10) developing a sustainable teacher profession; and 11) conducting teachers' performance assessments (Delis and Ida, personal communication, June, 9, 2014).

MAN Cipasung held several activities related to the development of teacher competence, they are: 1) conducting empowerment of teacher working groups; 2) conducting scientific writing training; 3) conducting workshop of making lesson plans; 4) conducting workshop on integrated curriculum; 5) conducting workshop on curriculum 2013; 6) conducting class action research activities; 7) conducting information and technology training; 8) conducting teachers' conference activity; 9) improving effectiveness of teacher working groups; 10) improving effectiveness of school working group; and 11) conducting lesson study (Ipit and Amay, personal communication, June, 9, 2014).

MAN Ciwaringin Cirebon has professional teachers with the following capabilities: 1) having the ability not to limit the space for learners in learning; 2) having the ability to assign tasks independently; 3) having the ability to design learning activities that can stimulate learners; 4) having the ability to encourage learners to make the environment as a source of learning; 5) having the ability to start lessons from where and what competencies need to be, and what lessons need to be emphasized; 6) having the ability to compare the pretest result with posttest result; 7) having the ability to determine mastery of learning result; 8) having the ability to do coaching in extra-curricular activities; 9) having high work ethic;10) having pride to be a teacher; 11) having the ability to act properly; 12) having the ability to accept the condition of learners; 13) having the ability to guide the practice of religion; 14) having the ability to control the practice of religion; 15) having the ability to direct the practice of religion; and 16) having the ability to maintain religious harmony (Alhakim, personal communication, June, 10, 2014).

The development of teacher competence in implementing Islamic education teaching is carried out by the principal and other school components based on guiding principles of teacher competence, they are: 1) teacher competence development is conducted regularly and continuously; 2) providing knowledge development, understanding, and implementation of competence to teachers; 3) creating and developing the institution of teacher competence development and professionalism; 4) providing facilities for teacher competence development; 5) encouraging individual teacher to do efforts in developing competencies; 6) cooperating with related parties; 7) monitoring; and 8) making the center of learning resources together as the core institution of teacher competency development.

\section{The Practice of Islamic Teaching}

The practice of Islamic teaching in MAN 1 Bandung can be described as follows: 1) the practice of Islamic teaching is aimed to improve faith;2) Islamic teaching is performed regularly and programmed; 3) its implementation involves other elements outside school; 4) the practice of Islamic teaching is done by empowering its own strength; 5) paying attention to effective time; 6) making Islamic teaching as a vision of school; 7) the practice of Islamic teaching is motivated by empowering words or terms such as making every day like Friday; 8) making technical guidance of Islamic teaching; 9) taking into account the inclusiveness and tolerance 
aspects; and 10) the practice of Islamic teaching on madrasa is done variably (Satria and Yadi, personal communication, June, 11, 2014).

The practice of Islamic teaching in MAN 1 Bandung was carried out with various program activities, they were: 1) congregating for prayer activities; 2) scheduling Dhuba prayer; 3) implementing Dzubur prayer in congregation; 4) implementing religious lecture; 5) conducting teacher recitation activities; 6) commemorating memorial days of Islam; 7) forming nasyid group; 8) reciting shalawat (praising God and prophet); and 9) conducting short religious camp. The practice of Islamic teaching is done through various methods, they are: 1) exemplary; 2) habituation; 3) advice; 4) supervision; and 5) punishment (Hamzah and Satria, personal communication, June, 11, 2014).

The description of Islamic teaching in MAN Cipasung Tasikmalaya is as follows: 1) the implementation of Islamic teaching is programmed;2) the practice of Islamic teaching is carried out with measurable planning; and 3) the practice of Islamic teaching is varied. The program of Islamic teaching is carried out in various forms, they are: 1) reciting Qur'an; 2) memorizing Qur'an; 3) reciting shalawat in congregation; 4) celebrating the anniversary of Islam; 5) doing sunnah prayer activities; 6) reciting shalawat, 7) delivering preaches; 8) conducting speech contest activities; 9) doing social work activities; 10) implementing apprentice activities; and 11) doing sunnab fasting (Delis and Tia, personal communication, June, 9, 2014).

The description of Islamic teaching at MAN Ciwaringin is as follows: 1) the practice of Islamic teaching can be carried out inside and outside the institution; 2) the practice of Islamic teaching considers the financial aspect; 3 ) the practice of Islamic teaching aims to invite others; 4) making a continuity of Islamic teaching program; 5) oriented to the competence of graduates; 6) performed in stages according to the academic ability of students; 7) organizing activities of religious teachings in a coordinated way; 8) the practice of Islamic teaching is carried out regularly; 9) the practice of Islamic teaching is carried out variably; and 10) doing school's prime activities (Ajat, personal communication, June, 10, 2014).

The implementation of Islamic teaching in MAN Ciwaringin was done with various forms of programs, they were: 1) the practice of animal slaughtering; 2) visiting sacred villages; 3) conducting pilgrimage simulation practice; 4) conducting practice of marriage ceremony; 5) conducting practice of divorce procedure; 6) attending and researching traditional ceremonies; 7) conducting practice religious activities; 8) memorizing Qur'an; 9) celebrating of Prophet Muhammad's birth; 10) da'wah guidance; 11) forming marawis group (tambourine); 12) ta'ziyah (visiting someone's death to show our condolence); 13) doing social work; 14) giving alms; 15) reciting Qur'an competition; 16) making calligraphy; 17) comprehending Arabic books of Islamic resources. The methods used in the practice of religion in MAN Ciwaringin Cirebon are: 1) habituation; 2) exemplary; 3) advice; and 4) supervision (Ajat, personal communication, June, 10, 2014).

\section{Supporting and Inhibiting Factors}

There were several factors supporting the implementation of teacher competency policy in the practice of Islamic education teaching at MAN 1 Bandung, they were: 1) human resources, especially certified teachers; 2) the practice of simultaneous and powerful Islamic education teaching; 3) 30\% of teachers are post graduate; 4) adequate facilities and infrastructure; 5) a large number of learners; 6) achievements; 7) supportive communication atmosphere; 8) attitude of teachers who respect the principal and peers; 9) unsaturated bureaucracy; 10) availability of standard operating procedures; 11) good communication with the environment and external agencies; 12) teacher professionalism guidance and development activities in the organization run optimal; and 13) religion lessons are relatively numerous. The inhibiting factors of teacher competence policy implementation in MAN 1 Bandung are: 1) resources that still need to be 
improved; 2) a large number of students; 3) need to improve teacher competence development activities such as lesson study (Yadi and Hamzah, personal communication, June, 11, 2014).

In MAN Cipasung, factors supporting the implementation of teacher competence policy in the practice of Islamic education teaching are: 1) good communication with school elements; 2) good attitude among peers as teachers; 3) the practice of varying religious teaching; 4) community support around school; 5) support from the school environment; 6) certified teachers; 7) the effectiveness of the institution of teacher competency development; 8) adequate facilities and infrastructure; 9) top classes; and 10) unpublished bureaucracy. The Factors inhibiting the implementation of teacher competency policy in the practice of Islamic education teaching are: 1) ethos of work that needs to be improved; 2) responses to new policies that still need to be improved; 3) attitude to information that is less precise; and 4) availability of SOPs that need to be completed (Ida and Delis, personal communication, June, 9, 2014).

The factors supporting the implementation of teacher competency policy in MAN Ciwaringin are: 1) extracurricular activities are numerous and varied; 2) full day class whichis featured class; 3) achievements of alumni studying abroad; 4) received a scholarship study; 5) cooperation with boarding school in creating Islamic education teaching; 6) human resources, especially certified teachers; 7) adequate facilities and infrastructure; 8) high level of religiosity; 9) achievements of the hafidz (memorizer) of the Qur'an; 10) there is a shared learning resources center with 33 rooms; 12) availability of official cars for the principal; 12) student achievement in many competition; 13) English learning program to Pare; 14) implementation of case handling by team. The obstacles in the implementation of teacher competence policy were: 1) extracurricular activities are numerous; 2) not all teachers have the ability to guide the practice of religion; 3) a large number of learners; 4) lack of coordination with kyai; 5) lack of coordination with parents; 6) the facilities need to be improved; 7) teacher residence was quite far from school; 8) communication between coaches of extra-curricular activities needed to be improved; 9) reciting Qur'an program still needed to be improved; and 10) inadequate transportation when communicating with boarding school (Alhakim, personal communication, June, 10, 2014).

\section{Advantages and Shortages}

1. Advantages

Those three MANs featured advantages such as:

a. The three MANs had good human resources. Teachers in all three MANs were certified.

b. The infrastructure facilities in the three MANs had fulfilled and exceeded the standard. In all three MANs there were were dormitory buildings and Learning Center which was very supportive of guidance and improvement of teacher competence.

c. All three MANs have accreditation A. Accomplishments are achieved also by teachers and learners to the national level.

d. All three MANs had a lot of good quality students. These three MANs were one step ahead compared to the others in term of admission. Learners were not only from West Java but also from outside of West Java.

e. All three MANs had effective leadership. Excellence in human resources, facilities and infrastructure, achievements and interests of learners were the result of high-quality leadership. The formation of the attitude of school community mutually cooperate, maintain and develop the quality of the school are evidence of excellence leadership.

f. Islamic education teaching. The Islamic education teaching practice in all three MANs was implemented in a planned and various ways. Numerous forms of religious practice are the advantages because it had an important influence in realizing the vision and mission of Islamic education teachings in all three MANs. The practice of Islamic education teaching was a form of strong religious commitment. 
In addition to the advantages mentioned above, the advantages that made them different from others were:

a. MAN 1 Bandung had a strong Islamic education teaching by taking the spirit of Friday, which made every day like Friday in the practice of Islamic education teaching.

b. MAN Cipasung Tasikmalaya had a special institution handling the development of the profession and the competence of teachers under the coordination of vice principal on development of profession.

c. MAN Ciwaringin Cirebon cooperated with 42 boarding schools in order to strengthen the practice of Islamic education teaching.

2. Shortages

Shortages found in all three MANs were:

a. Great public interest to enroll their children cannot fully be fulfilled so that parents and prospective students who were not accommodated seek other alternatives to send their children to study in other schools.

b. Supporting facilities such as transportation or other equipment such as computers that were not sufficient cannot be fulfilled because it was associated with the shortages and other parties outside the schools that had authority.

c. Extracurricular activities were still less taken into consideration because the learners were numerous and the implementation is sometimes collided with academic activities.

\section{Products Offered}

In education policy implementation, there are four key factors that a policy can be implemented effectively, namely communication, resources, attitudes, and bureaucracy. This study offers the following ideas: 1) the principles of education policy implementation in order to be implemented effectively; 2) the principles of coaching competence of teachers; and 3) relevant ideas of practicing the principle of Islamic education teaching in school. These offered ideas are also linked to programs or other forms of activities related to the implementation of the policy, competence development of teachers, and the practice of Islamic teaching in madrasa.

1. Principles and program of policy implementation.

Shaleh $(1980$, p. 1) explains policy implementation as we have seen is the stage of policy making between the establishment of a policy such as the passage of a legislative act, the issuing of an executive order, the handing down of a judicial decision, or the promulgation of a regulatory rule and the consequences of the policy for the people whom it affects. It means that policy implementation should have positive impact on every person. In the context of education, the policy implementation should provide positive impact on teachers, administrative staff and the students themselves. The wider impact is the achievement of educational ojectives of the school. Based on the policy implementation, Edward III argues several factors that can influence the successfull implementation including: 1) communication; 2) resources; 3) disposition; and 4) bureaucratic structure (Edward III, 1980, p. 10). The Figure 1 illustrates the model of implementation approach proposed by Edward. 


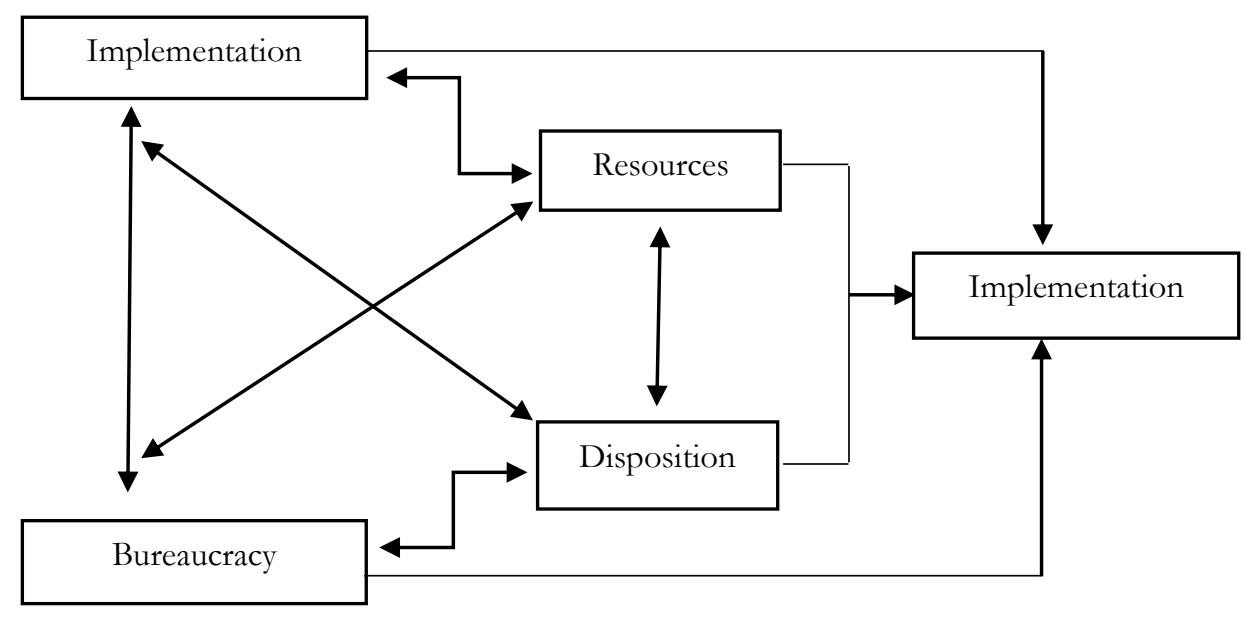

Figure 1. Model of Implementation Approach According to Edward III (1980, p. 148).

Good communication requires several aspects namely: 1) transmission; 2) consistency; and 3) clarity. Transmission has indicators as follows: no misinformation, hierarchy existence, information channel and objective understanding. The consistency has several indicators namely: continuous consistency, understanding conflict in policy implementation. Clarity has some indicators namely: understanding policy instruction, understanding policy complexity, consensus and responsibility (Winarno, 2012, p. 177).

In the aspect of communication as a component of policy implementation, researchers offer related notion principles and effective form of communication in policy implementation, they are: 1) the presence of those who assist in the implementation of policies; 2) their administrative systems in the form of a formal letter; 3 ) the utilization of technological facilities; 4) creating a community; 5) high intensity and continuity; 6) communicating individually; 7) using a variety of approaches/ways; 8) briefing after the flag ceremony; 9) conducting formal meeting; 10) monitoring; 11) informality; 12) senior teachers use the media; 13) instilling a sense of responsibility; 14) discussed object relates to the duties and functions; 15) good communication principles; 16) good quality communication; 17) making good service; 18) being a good servant of the state as the goal.

Resources as one of the important factors of an implementation can be accomplished with a good education to achieve a smooth policy implementation. Resources in organization covers human and non human resources (Sudarto, 2017, p. 93). Therefore, a successful educational program requires good supporting resources namely budget, human resources, system cooperation among teachers and principals, cooperation between teachers and quality assurance unit. One of the sources that can be optimized is the cooperation between schools and parents (Suherman, 2017, p. 6).

Referring to the above explanation, it can be concluded that there are some ideas that the researcher offers, they are: 1) authority, duties and responsibilities of personnel are clear; 2) good skills possessed by the related resources; 3) fostering human resources as scheduled; 4) fostering human resources effectively and efficiently; 5) improving the quality of human resources continuously; 6) conducting individual approach; 7) improving the quality of human resources of institutions; 8) creating programs and institutional structures; 9) capabilities; 10) professionals in the field; and 11) experienced.

Attitude is one of the important aspects in the implementation of education policies. According to Edward III (1980), the attitude aspect as part of the policy implementation has several components: 1) wisdom; 2) decision; and 3) initiatives. Offered notions related to the implementation of education policies include: 1) aiming to improve services; 2) the attitude of 
obedience to the policy; 3) prioritizing deliberation in policy implementation; 4) trying to have good attitude; 5) having the initiative in explaining the policy; 6) having the ability to use a certain momentum in delivering policies; 7) having the wisdom to improve the state of implementation of the policy.

Effective policy implementation requires the bureaucracy in the implementation. The aspect of bureaucratic structure is also one of the important elements that determine the success of implementation of a policy (Sulistyadi, 2014). In the field of education, education bureaucracy is required that is able to adapt to the dynamics of environmental change and understand the needs of the communities served (Solichin, 2015, p. 175). Referring to the above description, the standard of bureaucratic structure to implement education policy include: 1) availability of Standard Operating Procedures (SOP); 2) the readiness of facilities in supporting the bureaucracy; 3) having the ability to understand the different implementation; 4) good oriented; 5) having priority in achieving the goals; 6 ) having wisdom in addressing the implementation of the technical differences; and 7) providing ease. To get full understanding on principles and program of policy implementation, the Table 1 entails those information.

Table 1. Principles and Programs of Policy Implementation.

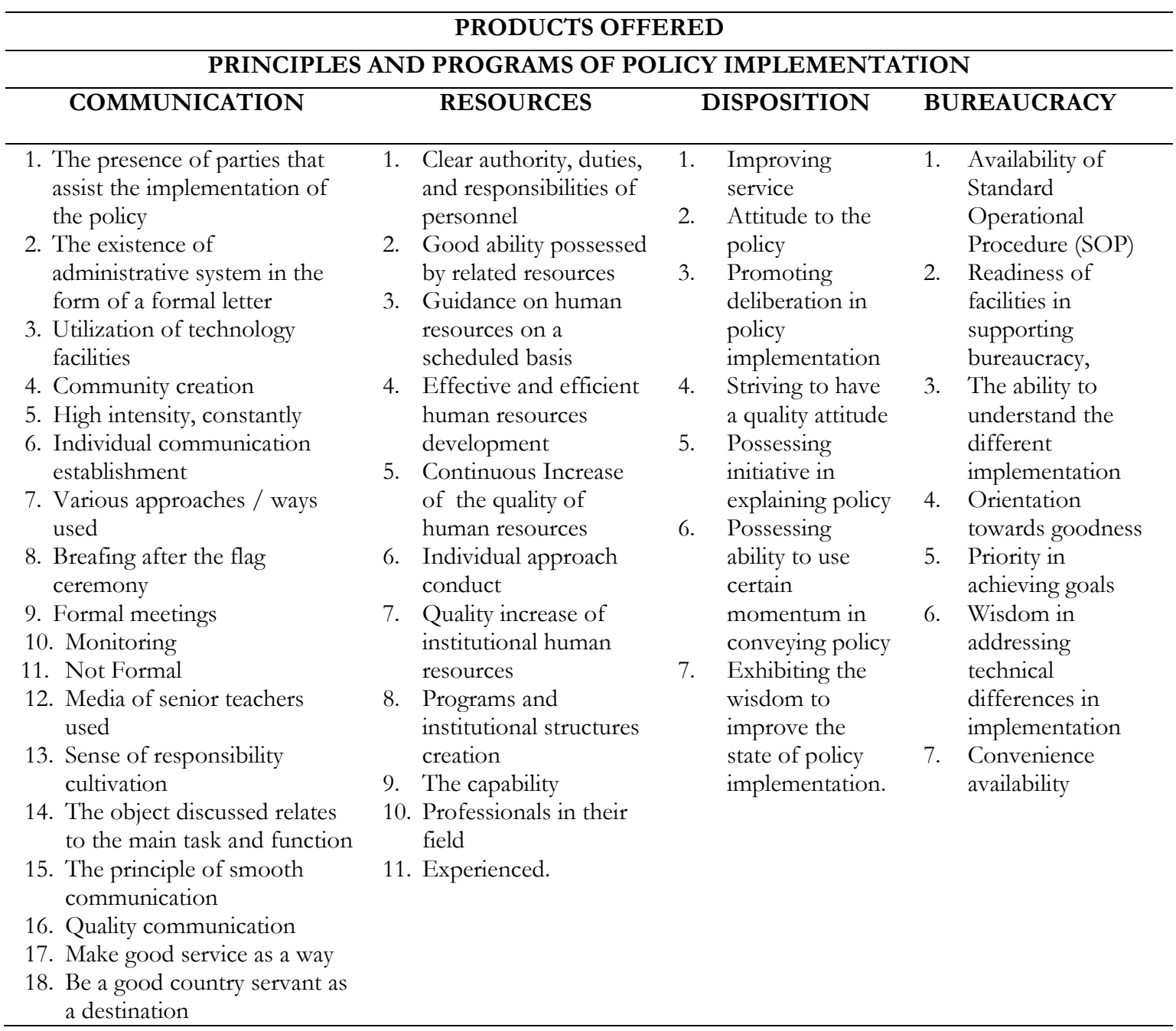

2. Principles and coaching programs teacher competence.

The effort of building competence of teachers needs guidance in order to create a professional teacher. Efforts to increase the competence of teachers in schools in the process of teaching and learning in addition to the responsibility of the leadership of the institution as a 
leader, the teachers are also required to make efforts to improve professionalism and credibility. The effectiveness of teachers in developing interpersonal relationships, relationships based on aspects of interrelationship, sensitivity, attention, trust, no abuses among teachers. They also communicate with parents and always encourage students to do their best. They also have a record of student progress and tell students to let students know the progress.

Based on the result of three MANs above, it is found that the principles of coaching teachers competence are: 1) maintaining professionalism; 2) having the ability to adjust to changes in the current situation; 3) having the ability to guide; 4) working to improve the competence; 5) knowing, understanding and implementing competence; 6) creating and developing specialized agencies and the professional development of teacher competence; 7) completing the infrastructure; 8) being capable of cooperating; 9) being capable of conducting surveillance; 10) having the ability to co-operation with community programs; 11) creating programs that support teachers competence; and 12) having the commitment to increase the competence of teaching.

Developing teacher competence can be implemented by preparing and carrying out related programs. Programs that are related to professional development and competence of teachers include: 1) training curriculum 2013; 2) deliberation of subject teacher; 3) lesson study; 4) conducting teachers working group; 5) madrasa working group; 6) IT training; 7) increasing mastery aspects of information technology; 8) utilizing joint learning resource center; 9) training scientific writing; 10) conducting workshop of lesson plan; 11) training action research; 12) profession sustainable development; and 13) teacher performance assessment. From some of the above phrases, important points relating to the ability of teachers can be concluded as follows: 1) improving teacher competence continuously; and 2) creating programs that support the teacher competence.

Teachers are required to undergo continuous professionalization. In the initial phase, ideally the institution takes the lead role. Another essential reason for the coaching and development of the teaching profession is the characteristic of the task that continues to grow in tandem with the development of science and technology, in addition to the internal reform of education itself. In general, this activity is divided into two types, namely practical methods (on the job training and development) and presentation techniques or methods of simulation (off the job training and development). Practical methods consist of job instruction training, internship, internship, assistantship or temporary assignment, job rotation, personal career planning, executive training, astrology assistant (guidance, counseling, and monitoring). Information presentation techniques and simulation methods include formal course methods, by self (programming teaching, reading, correspondence courses), training by others (lectures and class courses), simulations (vestibule training by special trainers, management games, assessment centers), role playing, video presentations, laboratory training, and method of conference (Danim, 2002, p. 85).

Developing programs and professional skills of teachers can be either institutionalized or individualized. Professional development activities and professional development of teachers are usually done by the government or non-governmental organization. Form activities can be programming further study, upgrading, seminars, workshops, working groups teachers, professional guidance, comparative studies, and apprenticeships. Individual activities are the embodiment of teachers' innovation and creativity to continue to grow and develop (Danim, 2002, p. 187). In order to achieve full information on teacher competence development, the table 2 illustrate those principles and programs. 
Table 2. Principles and Programs of Teacher Competency Development.

\begin{tabular}{lll}
\hline \multicolumn{1}{c}{ PRODUCTS OFFERED } \\
\hline \multicolumn{1}{c}{ PRINCIPLES AND PROGRAMS OF TEACHER COMPETENCY DEVELOPMENT } \\
\hline \multicolumn{1}{c}{ PRIPLES } & \multicolumn{1}{c}{ PROGRAMS } \\
\hline 1. Maintaining professionalism & 1. Curriculum training \\
2. Adjusting to change in the current situation & 2. Inisiating subject teacher consultation \\
3. Ability of teachers to guide & 3. Lesson study \\
4. Seeking to improve competence & 4. Inisiating teachers working group \\
5. Knowing, understanding and able to implement & 5. Madrasah working group \\
competence & 6. IT training \\
6. Developing specialized institutions of & 7. Improving the mastery of information \\
professional development and teacher & technology \\
competence & 8. Using learning center \\
7. Completing facilities and infrastructure & 9. Scientific writing training \\
8. Ability to cooperate & 10. Workshop of lesson plan and integrated \\
9. Ability to supervise & curriculum \\
10. Ability to cooperate with the community & 11. Classroom action research training \\
program & 12. Sustainable culture development \\
11. Creating programs that support teacher & 13. Implementing teacher performance \\
competence & & assessment \\
12. Having commitment to improve the &
\end{tabular}

3. The principles and program practicing of Islamic teaching in madrasa.

The practice of Islamic teaching in madrasa is an activity that has a value that is important for the achievement of madrasa in realizing the vision, mission, and purpose of school. There are some ideas of principles and programs of practicing Islamic teaching in madrasa. Practice of the principle of islamic teaching in the madrasa, are: 1) aiming to fill the faith; 2) conducted regularly and programmed; 3) empowering own strength; 4) noting the effective time; 5) forming various activities while practicing Islamic teaching; 6) the practicing islamic teaching is implemented in the internal organization; 7) noting the financing ability; 8) aiming to encourage others in goodness; 9) making the activity of this religious teaching practice as part of the vision of the madrasa; 10) oriented to the competence of graduates; 11) there is a hierarchy correspondence to academic ability of students; 12) institution practice of internal and external Islamic teaching implementation; 13) noting inclusivity and tolerance aspect; 14) the availability of facilities and infrastructure; 15) availability of funds; 16) conducting the event to consider at certain moments; 17) religious activity is an activity that is favored in the schools. Practice religious teachings in schools have a varied program form. Kahmad (2009) mentions there are five religious dimensions in human being, namely, the dimension of religious practice, the dimension of belief, the dimension of religious knowledge, the dimension of religious experience and the dimension of consequences.

Offered ideas that researchers deliver related to Islamic teaching activities in schools are: 1) praying together; 2) Dzubur congregational prayer; 3) religious preaches; 4) reciting Qur'an; 5) tabfidz Qur'an, 6) celebrating great days of Islam; 7) sunnah prayer activities; 8) initiating activities with prayer; 9) nasyid (vocal group); 10) reciting shalawat; 11) short Islamic camp; 12) speech competition; 13) social service; 14) apprentice; 15) sunnab fasting; 16) activity visiting indigenous villages; 17) practice how to slaughter animals; 18) practice of pilgrimage; 19) practice of marriage; 20) practice how to divorce; 21) attending and examining the ceremonies; 22) celebrating prophet's birth; 23) dakwah guidance; 24) tambourine (marawis); 25) ta'riyab; 26) calligraphy; 27)comprehending the Arabic books of Islamic resources; 28) studying fiqh; 29) 
study the book of grammar (tools); and 30) giving shadaqah. To get clearer picture on Islamic practices by students in the school, the Table 3 illustrates those activities.

Table 3. The Principles and Programs of Islamic Teaching Practice in Madrasa.

\begin{tabular}{lll}
\hline \multicolumn{1}{c}{ PRODUCTS OFFERED } \\
\hline \multicolumn{1}{c}{ MHE PRINCIPLES AND PROGRAMS OF ISLAMIC TEACHING PRACTICE IN } \\
MADRASA
\end{tabular}

In general, conceptual model on teacher competence policy implementation can be implemented in the following stages as shown in the Figure 2. To produce a model of policy implementation on teacher competence in practicing Islamic teaching in madrasa, there are some aspects to consider namely input, process and output. Input has something to do with principles of program development, implementation, education policy and teacher competence. When it comes to process, every stakeholder must participate in upholding the principles and implement the agreed and planned program. The parties involved include: 1) the principal of madrasah; 2) teacher; 3) student; 4) administration staff; 5) material; 6) method and 7) evaluation. 
Good process is expected to yield good product or output. In this context it refers to madrasah that has the following characteristics: excellence, academic achievement and religious habit formation. These good outputs may attract good trust from other parties including public and government. Their trust can be considered as an outcome.

As a customer of educational service, the society has a function to play a role as a quality assurance od educational service of a particular school. It is imperative for the schools to boost their performance in particular the educational process to achieve better service for the students in terms of moral, intellectual and skill that they need to seize the life they encounter in the future.

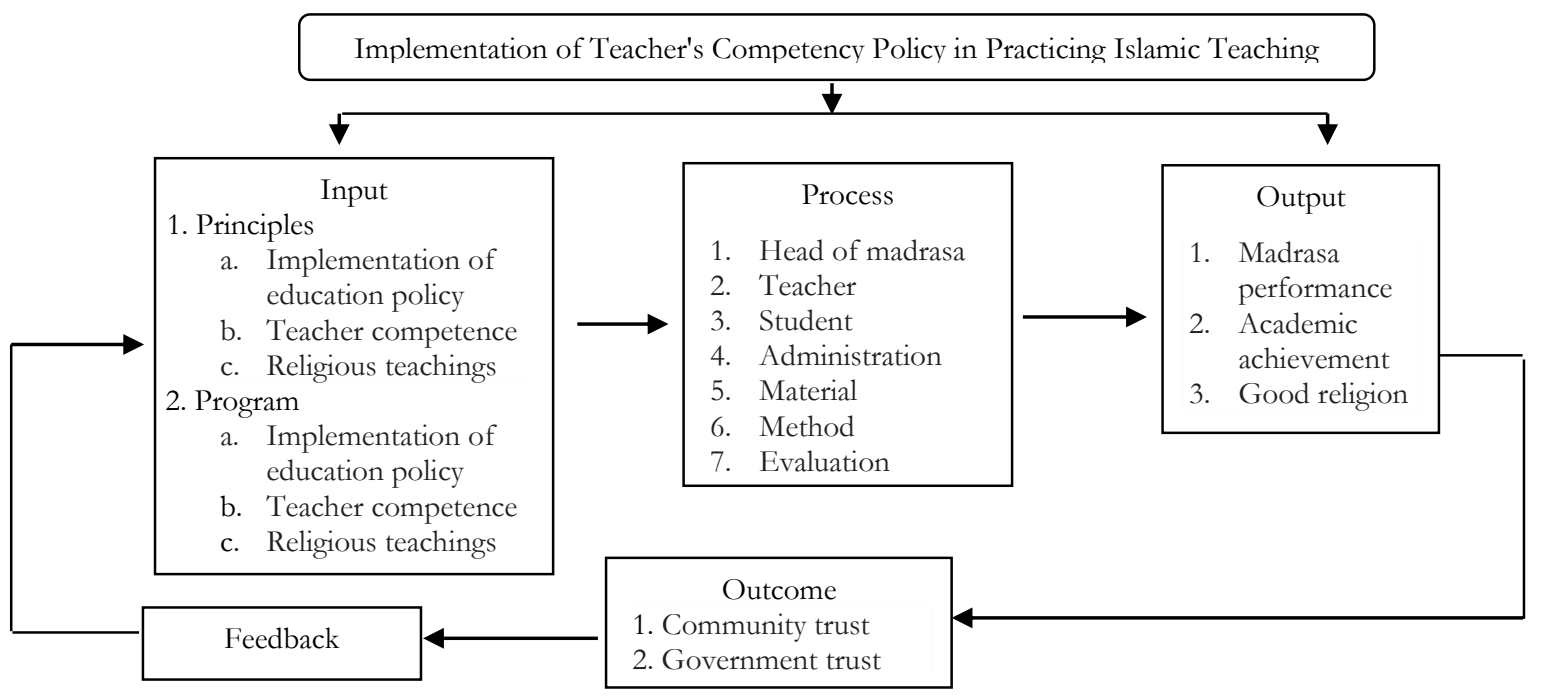

Figure 2. Conceptual Model Implementation of Teacher's Competency Policy in Practicing Islamic Teaching.

\section{CONCLUSION}

Implementation of teacher competence policy in the practice of Islamic education teaching in schools can be effectively carried out with the cooperation among them is very usefull. Competency of teachers in madrasa has been fostered and developed through the principles of enhancing the competence of teachers and produced professional teachers. Practice of Islamic teaching in madrasa has been carried out either by using principles varied forms of programs. Policy implementation competence of teachers at madrasa is supported by: human resources, especially certified teachers, practice of Islamic teaching is simultaneous and powerful, infrastructure are adequate, achievement institutions, teachers and students and leadership. Policy implementation of competence teachers at madrasa has inhibiting factors includes: resource that still needs to be improved, response to new policy that still needs to be improved, infrastructure, coordination. The advantages and shortages of the three MANs in West Java related to the policy implementation competence of educators in practice religious teachings include: a) advantages include human resources, infrastructure, achievement, input learners, leadership, and practicing Islamic teaching. Shortages that are owned by three MANs in West Java are limitations in meeting the great public interest to send their children to MANs, supporting facilities, and management of extracurricular activities that need to be improved.

\section{BIBLIOGRAPHY}

Ajat. (2014, Juni 10). Teacher competence implementation.

Alhakim, L. (2014, Juni 10). Teaching competence implementation. 
Danim, S. (2002). Inovasi pendidikan: Dalam upaya peningkatan profesionalisme tenaga kependidikan. Bandung: Pustaka Setia.

Delis. (2014, Juni 9). Teaching competence implementation.

Hamzah. (2014, Juni 11). Teaching competence implementation.

Ida. (2014, Juni 14). Teaching competence implementation.

Indiahono, D. (2009). Kebijakan publik: Berbasis dynamic policy analysis. Yogyakarta: Gava Media.

Ipit, \& Amay. (2014, Juni 9). Teaching competence implementation.

Kahmad, D. (2009). Sosiologi agama. Bandung: Remaja Rosdakarya.

Law no. 14 on teachers and lecturers. (2005). Ministry of Education, Republic Indonesia.

Muhaimin. (2009). Pengembangan kurikulum pendidikan agama Islam. Jakarta: Raja Grafindo.

Satria. (2014, Juni 11). Teaching competence implementation.

Shaleh, A. R. (1980). Penyelenggaraan madrasah petunjuk pelaksanaan administrasi dan teknis pendidikan. Jakarta.

Solichin, M. (2015). Implementasi kebijakan pendidikan dan peran birokrasi. Religi: Jurnal Studi Islam, 6(2), 148-178. Retrieved from http://www.journal.unipdu.ac.id/index.php /religi/article/view/486/433

Sudarto, Z. (2017). Implementasi kebijakan penyelenggaraan pendidikan inklusif. Jurnal Pendidikan (Teori dan Praktik), 1(1). Retrieved from https://journal.unesa.ac.id/index.php/ $\mathrm{jp} /$ article/download/369/202

Suherman, S. (2017). Analisis implementasi kebijakan pendidikan karakter. Jurnal Administrasi Pendidikan, 21(2), 68-80. Retrieved from http://ejournal.upi.edu/ index.php/JAPSPs/article/view/6676/4544

Sulistyadi, H. K. (2014). Implementasi kebijakan penyelenggaraan layanan pendidikan inklusif di Kabupaten Sidoarjo. Jurnal Kebijakan dan Manajemen Publik, 2(1). Retrieved from http://journal.unair.ac.id/download-fullpapers-kmp08e4cbae56full.pdf

Winarno, B. (2012). Kebijakan publik: Teori, proses, dan studi kasus. Jogjakarta: CAPS.

Yadi. (2014, Juni 11). Teaching competence implementation. 